\title{
Study Power of Supreme Leader in Iran Judicial System
}

\author{
Abdollah Habibi ${ }^{1}$, Dr. Seyed Hossein Al Taha ${ }^{2} \&$ Dr. Rahim Sayah ${ }^{3}$ \\ ${ }^{1}$ Ph.D. student of jurisprudence and Islamic law, non-profit University of Imam Ali (A), Ahvaz, Iran \\ ${ }^{2}$ Assistant Professor in Shahid Chamran University of Ahvaz, Faculty of Theology, Ahvaz, Iran \\ ${ }^{3}$ Assistant Professor in Petroleum University of Technology, Ahvaz Faculty of Petroleum, Iran \\ Correspondence: Abdollah Habibi, Ph.D. student of jurisprudence and Islamic law, non-profit University of \\ Imam Ali (A), Ahvaz, Iran. E-mail: abdollah.habibi1352@gmail.com
}

Received: June 17, 2017

doi:10.5539/jpl.v10n4p180
Accepted: July 18, $2017 \quad$ Online Published: August 30, 2017

URL: https://doi.org/10.5539/jpl.v10n4p180

\begin{abstract}
After the Islamic Revolution, the issue of the powers of the supreme leader was only considered in terms of scientific attention. However, the importance of this issue was more obvious, when was brought from the scientific scope to the practice scope. Should adopt religious support of these principles in the Constitution of the Islamic sources, especially traditions, with the Islamic Revolution and the rule of the supreme leader at the helm of the Islamic Republic of Iran and his authority in the Constitution. In addition, investigate the opinions of jurists, especially those who opposed or believed to limitations in supreme leader's authority to come closer to what is right. In this study, two titles of supreme leader authority and judgment included, that both have high importance In Shi'a jurisprudence.

Certainly, there are differences in the powers of the Plenipotentiary, and this case flows in the exercising sovereignty towards the general judicial policies. Since the judges permitted by Plenipotentiary, and in most cases are not religious jurisprudence, so the position and value of judgments rendered by them are evaluated, and even religious jurisprudential judges and above all Head of the Judiciary, all in the application of laws are obliged to comply with the Plenipotentiary. The main goals of this thesis are studying the power of plenipotentiary within the scope of form rules and establishing special courts and the substantive rules as retribution, amnesty and repent, that all show the extent of the powers of the Plenipotentiary in the judicial system. Judgments rendered can be very efficient, especially in cases of conflict between judgments rendered and his ratings and comments in the benefit observance of society and Islam.
\end{abstract}

Keywords: plenipotentiary, authority, system, judicial

\section{Statement of the Problem}

After the Islamic Revolution, the issue of the powers of the supreme leader was only considered in terms of scientific attention. However, the importance of this issue was more obvious, when was brought from the scientific scope to the practice scope. Should adopt religious support of these principles in the Constitution of the Islamic sources, especially traditions, with the Islamic Revolution and the rule of the supreme leader at the helm of the Islamic Republic of Iran and his authority in the Constitution. In addition, investigate the opinions of jurists, especially those who opposed or believed to limitations in supreme leader's authority to come closer to what is right.

Ayatollah Boroujerdi (RA) about the Guardianship of the Islamic Jurist based on rational arguments proved the importance of government and Guardianship of the Islamic Jurist and believe that if we informed of implying insufficient hadiths on Guardianship of the Islamic Jurist, can prove it through rational argument (Tabatabai Boroujerdi).

Allameh Tabatabai says he believes humans instinctively seek the most informed, best and fairest person that in the absence is the supreme leader of Islam. He did not use jurisprudence approach based on delegation of authority from above to prove this issue, but applied rational and philosophical reasoning (Zahrani). He said; by the order of nature, the presence of a supreme leader position in each community is essential to maintaining higher interests. Islam goes alongside nature (Khoei, 1989).

From the Motahhari's viewpoint qualified jurists appointed to Guardianship by the infallible Imams and 
considered as their Deputies in the era of absence (Allameh Tabatabaei).

Ayatollah Khoei on the religious provisions' implementation (Islamic Disciplinary rules), which is the responsibility of the religious judge, says: "running powers legislated for the public benefit and health to prevent decay and destroy and root out crime, rebellion, invasion and aggression (Arefi).

Ayatollah Bahjat: A supreme leader must have the ability in all spiritual and material matters and be an indicator, solvents, guide and problem solver. As a result, supreme leader must have all aspects of Imam except Imamah and what is specified for the Imam, to be able to implement Islam in the society. Otherwise, in the absence of organization and governing procedure, the enemies will not let implement the government and the religion of Islam (Baqi Zadeh, 2006).

Ayatollah Khamenei: "leadership of the community and social aspects in each era are pillars of our Twelver (Athnā'ashariyyah) religion and rooted in the principle of Imamah. So everybody, who based on reasons, believes its opposite, is excused, but at the same time, he is not permitted to cause conflict and separation" (Jannati, 1991).

So the purpose is to determine the broad powers and at the same time the necessity of leadership, within the legal and religious standards framework, which is essential to provide prosperity and security of the population and implementation of public affairs. On the other hand, in the constitutional law of the Islamic Republic, Head of the country has supervision and comprehensive line of sight on legislative, judicial and executive powers on all matters, and somehow this institution legitimizing all other government institutions. Islamic Republic of Iran's Constitution, knows the absolute Guardianship of the Islamic Jurist as a link and the connection point of the ruling powers. Given that the system of an absolute Guardianship of the Islamic Jurist, is unique in the world legal system, so the current regime in Iran is not a presidential regime based on absolute separation of powers, and not a parliamentary regime based on the relative separation of powers.

Naraqi (d. $1245 \mathrm{AH})$ writes: "Velayat-e faqih is a consensus between Shiites and none of the jurists are not in a problem in Guardianship of the Islamic Jurist (Najafi, 1986).

Ibn Idris (jurists sixth century AH) writes: "Imams allocate to Shia jurisprudents all of the possession (Rajai, 2007).

Saheb Javaher (d. 1266 AH) says: "Never felt jurisprudence, who tempt in the Guardianship of the Islamic Jurist, and did not understand the meaning and code words of immaculate Imams (Alnabravy, 1996).

This article intends to review and analyze features, dimensions, and aspects of governmental jurisprudence ijtihad (methodology) in the Islamic Republic with an emphasis on legal-political thoughts of Imam Khomeini (RA). In addition, based on this assumption that jurisprudential understanding of contemporary jurists especially Imam Khomeini (RA) from the Sharia and jurisprudence resources, causing to transition from personal jurisprudence to the governmental jurisprudence. Hence, in addition to the commonalities of the non-governmental approaches to jurisprudence, other jurisprudential features are in his works and ijtihad that causing differentiation with other jurisprudence approaches (HeydarPour, 2012).

Seyed Sajad Izadehi stated in "Imam Khomeini and elevating the status of governmental jurisprudence" that:

Shiite jurisprudence does not means allocate jurisprudence, to individual matter and constant jurisprudence principles are in line with the effective administration of the society towards material and spiritual prosperity, which considered by some jurists (Mir Mohammad Sadeghi, 2014).

So this study using descriptive analysis method seeks to answer the question that how much is the scope of authority the Supreme Leader as the Islamic leader, according to the changing circumstances of time and place and due to the creation of deadlocks that may be achieved in the formulation and legislation of these issues and the implementation of legal rules? 1. Are Supreme Leader authorizations in judicial decisions primary or secondary rules? 2. How could Supreme Leader apply his mind in the scope of the judicial system (formal rules)? 3 Could Supreme Leader apply his mind in the implementation of religious provisions, retribution, forgiveness, and repentance?

\section{Scope of Supreme Leader Powers and Duties in the Procedural Rules}

According to the principles of the judgment as a decision of the Court and Article 299 of the civil procedure code and the nature of the law; as a mean to guarantee the rights of persons as a citizen, and ensuring the rights of the ordinary people with each other, it can be acknowledged that the dignity of leadership in this regard has interference or a total or partial duty. Since the subject of Civil Procedure confluence with financial or private rights of persons' thoughts, Supreme Leader based on own permitted judges, granted authority to law to make a decision. 


\section{Study Special Jurisdiction}

The Code of Criminal Procedure is a nullity factor of the theory that, purpose legitimate all means. This means that should not discomfort all communities and vice versa to restore the altered order of the criminal procedure. Here we start an introduction to the discussion with a few questions:

1) What is the supreme leader role with respect to their powers and duties in the Code of Criminal Procedure? Is his role passive or active?

2) Does the supreme leader have right to form a criminal court, to trial the People?

We have to learn about authorities and their variants, in the law in question to discuss about the issue.

Code of Criminal Procedure: "a criminal trial divided in the Criminal Court I, the Criminal Court II, the revolutionary court, juvenile court and military courts." In this law, "the sector of a public court" is used as the court with jurisdiction 2 within the jurisdiction of the criminal court. Special Clerical Court (SCC) is also a criminal court, with jurisdiction over crimes of spiritual people, as stipulated in the regulations of the clerical court, passed in 1369, terms in 1384. Not mentioning SCC in the above article does not remove it from the criminal courts, but also shows not belonging the organizations to the judiciary and citing existence and its jurisdiction to the aforementioned code.

First investigation authorities are two categories: public authorities and dedicated authorities.

\section{Jurisdictions}

Dedicated judicial authorities, including a military court, the Revolutionary Court and the Special Court for the Clergy, that will be studied in order.

\section{Military Court}

The formation of military courts is in order to investigate offenses of members of the armed forces, the forces and members are marked in Article 1 of the Penal Code offenses of the Armed Forces, Act of 1382. The jurisdiction of military courts developed in two cases, and include the following:

A) The development of competence in accordance with the decision of the Expediency Council: Resolutions of the Expediency Council, was adopted under the delimitation of the jurisdiction of the military court on July 28, 1994.

B) Development of competence according to Supreme Leader's authorization: Under the provisions of Article 597 Code of Criminal Procedure: "investigate offenses, which Imam Khomeini and the Supreme Leader have stated, will conducted in court and prosecutor's offices in a military court, and are in authority of the this organization, as long as did not derogate". The deceased leader and the current leader of the revolution in two cases have developed military courts qualifications:

1) Crimes related to the duties of the staff of the Ministry of Information and records of classified information. in 1366 at the request of the Minister of Information, Imam Khomeini allowed to investigate "offenses related to the legal obligations of employees of the Ministry of Information and files including classified information and secrets of the Islamic Republic of Iran ", in the Judicial Organization of the Armed Forces.

2) Security Offenses and Crimes during military service: at the request of the Head of the Judiciary, the Supreme Leader in 1373 allowed to investigate Security Offenses and Crimes during military service in military courts.

\section{Revolutionary Court}

After the victory of Islamic Revolution in February 1979, were established Revolutionary Court in the country, in order to trial perpetrators of "crimes occurred before the revolution to strengthen the Pahlavi regime and establish and maintain influence strangers or occurs after the revolution against the Islamic Revolution of the Iranian nation."

According to the general policies of the Islamic Republic of Iran, guidelines are legal tasks of judicial and this will be done by the Absolute Supreme Leadership and Constitution proof it. With regard to the position of Supreme Leader in the legal system of jurisprudence, enforce jurisprudence is a divine order and has been granted to the infallible Imams. We live in the age of occultation and the Supreme Leader is the successor of eminent Imams. He has a duty to the Constitution about the advances of society to ideal point and proceed to judgment in the way of legislation and its implementation and solve problems arising from the interpretation or implementation of important cases, or solve the dilemma by providing their helpful comments, so the answer is definitely positive.

\section{Special Clerical Court}

Another dedicated court, which established in our country, is Special Clerical Court. A special feature that 
separated this Court from other studied is the lack of regulatory approval for its creation by the legislature and not belonging to the organization and the official establishment of the judiciary, but the establishment and operation under the authority of leadership (Daryabari, 2004).

The scope of the powers and duties of the Supreme Leader on the prescribed punishment, retribution, repentance and amnesty issues.

\section{Retribution}

Retaliation, however, is an individual right, but its implementation is the authority of the government even after fixation, like any other penalties, because it would need more accuracy and acquainted with the principles. Failure to abide by this principle will lead to chaos and possibly violate the rights of individuals and is incompatible with a caution need for the right to life. For this reason, the Articles 417 to 420 "IPC" have insisted on the need of permission from the Supreme Leader or his agent before the enforcement of retaliation by the avenger of blood. Article 417 notes that, "in the enforcement of retaliation, leadership or his agent permission is required". Article 419 stated the necessity of permission from the leadership and enforcement of retaliation by the enforcement of criminal sentences. Of course, in accordance with Article 418, the permission rite should not preclude the possibility of achieving the full realization of the right to retribution and retaliation for the right owner.

The impediment in former "Islamic Penal Code" was a lack of foresight to guarantee the case for the avenger of blood to action to retaliation of murderer without permission. In this case, the avenger of blood retaliation will be devoid of justification, because, in accordance with paragraph (c) of Article 302 "Islamic Penal Code", the murderer is deserving death, and as a result, retaliation and blood money abrogated from him (Khomeini).

\section{Repentance}

Note 1 of Article 114 of the Islamic Penal Code stipulates that, repentance of the bandit, before arresting or dominate him lead to abrogate prescribed punishment. The difference between this note with Article 116 of the Act returns to the time of repentance; in one, repentance happens before arresting or dominate perpetrator, in other repentance happens after arresting or dominate him, in this case, the punishment will not abrogated by repentance. Prescribed punishment by the imputation of in chastity, retaliatory punishment and blood money will not be abrogated by repentance of perpetrator (Article 116 of the Islamic Penal Code). It is said that, these punishments are the rights of the people and with the remission by the complainant, whether the perpetrator repents or not, criminal prosecutions will have abatement and if convicted, the punishment will be abrogated (Marashi Shoshtari, 1991). As the case of perpetrator punishment by ascertainment or acceptance of repentance, punishment will be abrogated or will be pardoned by the Supreme Leader. In discretionary punishment (grade one to five) with ascertainment of repentance, the court can impose regulations relating to mitigation of punishment. Perpetrator gets free from imprisonment or banishment, if the perpetrator repent, while performing punishment and Supreme Leader supposes freedom of perpetrator in crimes, led to prescribed punishment. In this case, changing prescribed punishment to discretionary punishment is another option under the authority of leadership.

\section{Amnesty}

We can say that amnesty is fully or partially waiving punishment arranged on crime, according to criticisms on term definitions of amnesty, and in order to achieve and provide a comprehensive definition of amnesty. The above definition covers all forms of issued amnesty by society and individuals, such as amnesty, private amnesty, and pardon victim or the victim's family (Ibid).

According to the introduction, the pardon victim or the victim's family is considered, as a waiver of right in unilateral legal acts, since is the one-sided legal action such discharge, resulting is the collapse of the right to retribution (Shahidi, 1989).

Private amnesty included all penalties such as original and additional have been issued in public and revolutionary courts and specialized courts (SCC, military courts) (Khansari, 1983).

In Note 2, Article 278 of the Islamic Penal Code regarding alternative imprisonment, about theft prescribed punishment in the third level and the thief conviction to life imprisonment, concluded that:

" ... if perpetrator repents, while performing punishment and Supreme Leader supposes freedom of perpetrator, he will be released from prison by Supreme Leader pardon. The Supreme Leader can also convert punishment to another discretionary punishment". Mentioned Note is extended this judgement to all imprisonment, which are not subject as punishment.

In principle, impunity from all or part of the main punishment has not impact on consequential penalties, unless the pardon offer stipulated to the penalties that typically are discretionary punishment. (Article 13 of the Penal Code of 
offenses in Armed Forces, January 2003).

For mitigation of punishment in Regulation Commission of Amnesty has not been determined criteria and a specific amount except in cases of execution that commuted to life imprisonment using the amnesty and also life imprisonment that commuted to fifteen years in prison. It seems that in this case Commission Amnesty detection and the Supreme Leader's confirmation is required.

\section{Prescribed Punishment}

Execution and enforcement or suspension of the prescribed punishment in the absence era of Imam is one of the eventful issues in Imamia jurisprudence. It is so acute that stimulated the jurists of the Ummah on both sides of the cross to offer a quite different viewpoint to each other and unfortunately, sometimes jurists got out of tolerance, and forced to bitter words. Mohaqeq Helli, leading jurist of the seventh century AD, in the book of " Sharaye' " decisive says: "in the presence of Imam (as) no one but him and who appointed by him are prohibited to execution and enforcement of Hodods" (Najafi, 1986). Then related permission to execution and enforcement of Hodods in the absence era to persons without naming.

\section{Conclusion}

1) About the Guardianship of the Islamic Jurist based on rational arguments, we proved the importance of government and Guardianship of the Islamic Jurist, and believe that if we informed of implying insufficient hadiths on Guardianship of the Islamic Jurist, can prove it through rational argument.

2) With regard to the earlier raised issues, one of the mentioned conditions is faith about the conditions and characteristics of Justice in the jurisprudence of holy Shiite. In addition, with regard to the concept of the twelve - Imam Shi'ism, we believe that judges of non-Shia, whether Sunni, etc., has not appointed right by the Supreme Leader. As if someone cannot accept Guardianship of the Islamic Jurist, which is a movement continuation of the prophets and imams, we cannot consider him Islam judge from the perspective of Shia.

3) One of the other conditions of a judge in Islam and the Shia school is being Male, and the meaning of being Male is being a man. In this treatise, we achieved the important issue that women can judge, by the traditions and sayings of scholars, whether the traditions negate the imperative of women, and this is not incompatible with the permission. This means that the judgment of women is not obligatory and necessary because the judge is a general obligation for those, who have the qualifications and this judgment is the negation of women.

4) The origin of right granting in the Islamic system, is not governing power. Whether in the Islamic judicial system, legislation is the only requirement of God's essence actions and in Islamic jurisprudence and exported laws of it, and on disputed legal or subjective issues must extract the correct rule or principle. This means that if the Leadership in contrary to judge of the court, issues other judgment, their view is not the violation of country law at all. He as a successor of Imam Mahdi (AS) has the task of promoting social objectives, one of the most important of which is a legal issue in accordance with the constitution and Islamic law.

5) The government of the Islamic Republic by Guardianship of the Islamic Jurist, in fact, is the government of the laws of God. the Supreme Leader is executive for religious regulations and criteria and take responsibility of independent leadership of innocent Imams for an emergency so Supreme Leader, in fact, is the guardian and executor of the divine commandments in religious community.

6) Because of intellectual and traditional reasons, we can conclude that, by the infallible Imams (as) as they were king or ruler, everything that has been stable guardianship for their own, was for jurists as well, and if we want to remove one case from this general rule, we need reason to indicate specialty of the case to infallible Imam.

7) In holy Islamic law, very difficult situation decreed for the Supreme Leader and the lack in one, destroyed leadership competence. However, his actions subjected to observation interest of the society and the Islamic Ummah. Things that Supreme Leader accepted according to the law, applies for his guardianship through a certain way. Observation of guardianship is necessary in terms of religious and the customary to him. When supreme leader, according to certain religious standards issued a rule, in accordance with the conditions, everyone, including himself is obligated to obey that rule.

8) As expediency in public jurisprudence considered, as that has not been in Shiite jurisprudence. However, in Imamia jurisprudence, people who legally have the right to interfere in financial or non-financial occupy as Supreme Leader, is valid only in expediency. 
9) If the government rule has incompatibility with another rule that before he issued, the new rule is valid because it is the last determination of the judge, and it is assumed that has been issued based on a title such as the necessity or expediency.

10) If the expediency of the Islamic system by detecting the Islamic judge is on joining to international organizations so it is required for States Parties, including the Islamic State to regard regulations and norms of international law. The main principles of the UN Charter is the principle of sovereign equality of members and of non-interference in matters, which are essentially within the national jurisdiction of countries. So, if we assume governing rule of the Islamic judge regime in case of spreads outside the territory, is in conflict with the mentioned principles, in this case, cannot be committed (at least) to being cross-border the governing rule of the supreme leader.

11) In examining the relationship between the Constitution with the Sharia and governing rules, can be said that religious instructions, including the Constitution, it means that whatever approved in the Constitution should base on Sharia. However, the reverse is not true, some of the provisions and objectives of Shariah have been set up in accordance with the requirements of time and place based on the Constitution. As a result, "expediency" that followed by the leadership or the State Exigency Council, can exceed the limits of constitution until placed in the Sharia framework. If we limited the Supreme Leader in the Constitution, Imam Khomeini could not make a decision about amending the Constitution in accordance with the law, because it was not in the Constitution.

12) There are cases that, Constitution has predicted legislation in relation with that. Decisions and commands that the Supreme Leader makes an issue in the first type, does not conflict with any legal regulation and also will not occur problem, because in such cases there is no law, which led to the violation with Supreme Leader's action.

13) It can be acknowledged that the dignity of leadership in this regard has interference or a total or partial duty. Since the subject of Civil Procedure confluence with financial or private rights of persons' thoughts, Supreme Leader based on own permitted judges, granted authority to law to make decisions.

14) Under the provisions of Article 597 Code of Criminal Procedure: "investigate offenses, which Imam Khomeini and the Supreme Leader have stated, will be conducted in court and prosecutor's offices in a military court, and are in authority of this organization, as long as did not derogate". The deceased leader and the current leader of the revolution in two cases have developed military courts qualifications. The conclusion is that Supreme Leader not only can have an ascertaining competency, but also can organize a judicial forum in a superior way.

15) The only authority that has general jurisdiction to legislation is the legislature. However, the decision of the judiciary the executive maybe based on the authority that the Supreme Leader has entrusted to it, because the independence of the three branches of the Constitution of the Islamic Republic of Iran is not absolute and three branches are applying under the absolute rule of the Supreme Leader and Leadership of the Ummah (Article 57). Explaining the laws is rights of the nation, especially criminal laws that determine limit the freedom of the individual (the third quarter of Constitution). Extremity acts of Supreme Leader is under Article 157 and in form of monitoring the legislation not in dictatorship form

16) Although the right of retaliation is fixed for the avenger of blood, but should have Supreme Leader's permission.

17) Supreme Leader is authorized to choose between retaliation and blood money, in condition that child of slain be a Muslim and a crime happened before he entered into puberty, so if not specified being Muslim of child, then in terms of occurrence of the doubt, Supreme Leader can only take blood money, and cannot apply vindication of retribution. Supreme Leader can only take blood money from slain's property in this case.

18) After agreeing on Leadership, Office of the Head of the Judiciary will send names of prisoners whom granted amnesty led to their freedom to the Prisons, Security and Corrective Measures to communicate to prisons across the country as soon as possible.

19) Many of the Shiite jurists thought, based on stop prescribed punishment in our times. As early Jihad is particularly for Imam and stopped based on the thought of majority in our time. There are many theories of jurists to run prescribed punishment in our times. Both theories documented to legal arguments, and it is not clear which is the majority and which is a minority. Stop theory, qualified social justification. In the case of non-performance the prescribed punishment, it will replace with discretionary religious punishment awarded by the judge, and its quantity and quality depend on the decision of the Judge. 
20) With regard to the raised issues about the powers and duties of the Supreme Leader, the first conclusion is; at first, the Supreme Leader is responsible for advancement Islamic society, under religious laws including the Constitution.

21) It can be concluded that issued rules by religious jurisprudent have the ability to revision and cancellation by the Supreme Leader, by performed studies on the status of permitted judges and primitive authorities Judges and Supreme Court revision except for religious jurisprudence, according to a lower position of the religious jurisprudence in front of the Supreme Leader.

\section{References}

Ahmad, K. S. (1983). Jame al Madark (Vol. 7). Saduq Press.

Allameh Tabatabaei, Mohammad Hussein, the translation of Al-Mizan, Allameh Tabatabaei scientific and intellectual foundation, vol. 4, pp. 207-211.

Alnabravy Nabil Abdol Mansour, The fall of the right to punishment between Islamic al-fiqh and legislation, Dar al Fikr Arabic Press, 1996.

Arefi, M. A. (n.d.). Political Thought of of Ayatollah Khoi. Qom: Book Garden Publishing.

Baqi Zadeh, R. (2006). leaves the Sun book of biographies Sheikh Al Salekin. Ayatollah Bahjat, Qom, Miras Mandegar (lasting legacy), pp. 101-102.

Code of Criminal Procedure, adopted in 2015.

HeydarPour, A. (1391). the introduction of Science and Law (3rd ed.). Jafari publication.

Hussein, R. (2007). the supreme leader and solving the system's problems. Revaq Andishe Publication.

IPC (suspending and inhibitor), adopted in 1976.

Islamic Penal Code (suspending), adopted in 1982.

Islamic Penal Code, adopted in 1982.

Islamic Penal Code, adopted in 1991.

Islamic Penal Code, adopted in 2013.

Jannati, H. (1991). the Guardian Council legitimacy document of system rule (2nd ed.). Sadra Publications.

Mehdi, S. (1989). Fall of commitments. Majd Publications.

Mohammed Zaman, D. S. (2004). prosecutor's office and special court in charge of the clergy. Revolution Center Press.

Penal Code, adopted in 1925.

Scope and retaliation and compensation law, adopted in 1982.

Zahrani, M. (n.d.). Political Thought of Allameh Tabatabaei. political science, (1), 89.

\section{Copyrights}

Copyright for this article is retained by the author(s), with first publication rights granted to the journal.

This is an open-access article distributed under the terms and conditions of the Creative Commons Attribution license (http://creativecommons.org/licenses/by/4.0/). 